\title{
Short communication: Pair housing dairy calves in modified calf hutches
}

\author{
L. Whalin, D. M. Weary, and M. A. G. von Keyserlingk ${ }^{1}$ \\ Animal Welfare Program, Faculty of Land and Food Systems, University of British Columbia, Vancouver, Canada, V6T 1 Z4
}

\begin{abstract}
The objective of this study was to test if body weight (BW) and starter intake increased and reaction to novelty decreased for preweaning Holstein heifer calves pair housed in modified hutches $(\mathrm{n}=8$ pairs) versus individually housed in a single hutch ( $\mathrm{n}=14$ calves). Calves were alternately assigned to housing treatment at d 5 of age. Cross sucking was recorded in 5-min scans for 30 min after milk feeding once per week over 14 wk. Calf health and BW were measured weekly from birth until approximately $88 \mathrm{~d}$. When calves were $60 \mathrm{~d}$ old they underwent a food neophobia test where they were exposed to a novel feed for the first time. Cross sucking was observed only 5 times (in 4 different pairs) over the entire milk-feeding period. Pair-housed calves ate more starter than individually housed calves [0.89 $(0.72-1.08)$ vs. $0.48(0.42-0.56) \mathrm{kg} / \mathrm{d}$; median and confidence interval], these calves also consumed 2.6 times more novel feed in the neophobia test $(150 \pm 27$ vs. 58 $\pm 20 \mathrm{~g} / 30 \mathrm{~min})$. We observed no effect of treatment on BW. We concluded that social housing in modified hutches promotes solid feed intake and decreases fearfulness in dairy calves.
\end{abstract}

Key words: welfare, group housing, behavior, neophobia

\section{Short Communication}

Dairy calves are often housed individually; the USDA (2016) reports that approximately $70 \%$ of US farms house preweaning heifer calves individually. Across all farm types, outdoor hutches or pens were the most common housing for preweaning heifers, with $40 \%$ of respondents indicating that they used hutches (USDA, 2016). However, raising calves in small groups provides welfare benefits without impairing calf health (Costa et al., 2016). Compared with individual housing, group housing results in decreased vocalizations at wean-

Received December 28, 2017.

Accepted February 17, 2018.

${ }^{1}$ Corresponding author: nina@mail.ubc.ca ing (Bolt et al., 2017), higher solid feed intake during the milk-feeding period (Bernal-Rigoli et al., 2012), and increased play behavior (Valníčková et al., 2015). These effects may be due to improved social skills and social buffering that helps mitigate the negative effects of stressful events (Boissy and Le Neindre, 1997). At weaning, calves are often exposed to several stressors simultaneously, including a diet change (Khan et al., 2011) and movement to a new pen (Pettersson et al., 2001). During this time, individually reared calves also experience their first physical contact with another calf.

The results of 2 recent studies suggest that pair housing with hutches may provide some benefits and be a feasible option for farmers (Pempek et al., 2016; Wormsbecher et al., 2017). However, those studies did not investigate the effects of pair housing on solid feed intake or reaction to novelty and were conducted on research farms. The aim of our study was to assess differences in performance and response to novelty between pair versus singly housed calves in hutches on a commercial dairy. We predicted that pair-housed calves would have greater starter intake, improved BW gains, and increased intake of novel feed.

This study took place on a commercial dairy farm located in Abbotsford, British Columbia, Canada, from May to December 2016. All procedures were approved by the UBC Animal Ethics committee under protocol \#A14-0245. Thirty female Holstein calves were separated from their dam and fed $4 \mathrm{~L}$ of colostrum replacer (Calf's Choice Total HiCal, The Saskatoon Colostrum Company, Saskatoon, SK, Canada) within 6 h of birth. At $24 \mathrm{~h}$, serum proteins were analyzed with an optical refractometer (Sun Instruments Corp., Torrance, CA); only calves with serum protein levels above $5.4 \mathrm{~g} / \mathrm{dL}$ were enrolled into the experiment. At d 5, calves were assigned to either individual housing ( $\mathrm{n}=14$ calves) or pair housing ( $\mathrm{n}=8$ pairs) based on birthdate and BW.

Individual calves were housed in hutches $(2 \times 1.2 \mathrm{~m})$ that included an outdoor space $(1.8 \times 1.2 \mathrm{~m})$. Paired calves were provided access to 2 of the same hutches and a shared outdoor space $(2.9 \times 1.8 \mathrm{~m})$. Calves were weaned, on average, at $60 \mathrm{~d}$ and were then moved to an indoor group pen $(2.8 \times 5.5 \mathrm{~m})$ that housed up to 6 calves. 
Calves were fed from a nipple bottle High Performance Pro-Gro calf milk replacer (150 g DM/L; Grober Nutrition, Cambridge, ON, Canada; 22\% CP, $17 \%$ crude fat, $0.15 \%$ crude fiber, on a DM basis) for 2 meals per day (at 0800 and $1630 \mathrm{~h}$ ). From d 1 to 7 calves were fed $6 \mathrm{~L} / \mathrm{d}$ and from $\mathrm{d} 8$ to $\mathrm{d} 35$ they were provided $10 \mathrm{~L} / \mathrm{d}$. At $\mathrm{d} 35$, the daily milk ration was then reduced to $6 \mathrm{~L} / \mathrm{d}$ over a 2 -d period, and on $\mathrm{d} 58$ milk volumes were further reduced such that weaning was completed by d 60 . During the milk-feeding period, all pair-housed calves were observed for cross sucking once per week using 5-min scan sampling for $30 \mathrm{~min}$ immediately following the afternoon milk feeding during 14 observational weeks.

Throughout the experiment calves were also offered ad libitum hay and a medicated calf starter (LifeLine; Otter Co-op, Aldergrove, BC, Canada; $18 \%$ protein, $4 \%$ fat, and $9 \%$ fiber, medicated with decoquinate at $50 \mathrm{mg} / \mathrm{kg}$, on a DM basis). Starter intake was recorded twice per week by disappearance; the amount of starter remaining was subtracted from the amount fed $24 \mathrm{~h}$ previously.

To account for effects of health on response measures, calves underwent a health check once per week (see Costa et al., 2015), recording temperature and signs of respiratory and digestive disorders. Body weight was estimated using a heart-girth tape (following Heinrichs et al., 1992). Respiratory health was assessed by visually inspecting nasal discharge, and a veterinarian or animal health technician listened for sounds of pulmonary infection during auscultation. On the day of examination, air temperature was recorded from a thermometer held inside the hutch. Diarrhea scoring followed De Paula Vieira et al. (2010), where 1 $=$ normal feces, $2=$ plaques but not watery, $3=$ watery and body temperature $<39.5^{\circ} \mathrm{C}$, and $4=$ watery and body temperature $\geq 39.5^{\circ} \mathrm{C}$. All calves displaying signs of illness were subject to a full veterinary exam and treated according to standard operating procedures for the farm.

A food neophobia test, exposing calves to $900 \mathrm{~g}$ of novel feed (TMR), was performed at $60 \pm 1 \mathrm{~d}$ of age; calves ranged from 52 to $69 \mathrm{~d}$ of age. The first 3 pairs and 1 individual were tested in the outdoor, wire enclosure in front of the hutch, which allowed calves to see each other (and thus potentially influence their responses); thus, the methodology was changed so that the rest of the calves were tested inside the hutch such that they could not see and were not visible to other calves when eating. In the case of pair-housed calves, the combined hutch was separated during the test into 2 single hutches using a gate divider. Calves were individually given access to the novel feed for $30 \mathrm{~min}$. The test bucket containing the novel feed was identical to that used for the routine feeding of calf starter and was placed in the same location of the pen. Behaviors during the test were recorded with a camera (Panasonic HDC, Osaka, Japan). The latency to approach the feed (muzzle $<5 \mathrm{~cm}$ from the bucket) was recorded. The amount of novel feed consumed was measured by disappearance at the end of the trial.

All analyses were performed with SAS (version 9.4; SAS Institute Inc., Cary, NC) using pen (individual calf or pair) as the experimental unit. Intake of calf starter $(\mathrm{kg} / \mathrm{d}), \mathrm{BW}(\mathrm{kg})$, novel feed intake (g/30 min), and latency to approach the feed (s) were considered dependent variables. Treatment differences in starter intake and BW over the trial were analyzed using a mixed model (with an autoregressive covariance structure) that included pen (specified as subject), treatment, age, and an interaction between treatment and age. Starter intake was transformed using a natural log to normalize residuals.

Novel feed intake (g/30 min) was analyzed with the GLM procedure including age, treatment, and the interaction between age and treatment. Analyses were completed with all the calves and without the first 7 calves, as those calves had been tested in the outdoor area with visual contact; results were similar, so the entire data set was used. The distribution of latency to approach the novel feed could not be normalized by transformation, so a Kolmogorov-Smirnov test was used to analyze treatment differences. In this case, age and the interaction between age and treatment were not considered. Results are presented as least squares means and standard errors of the mean for BW and novel feed intake, and results of the back-transformed data for starter intake are presented as geometric means and confidence intervals. We report F-values in

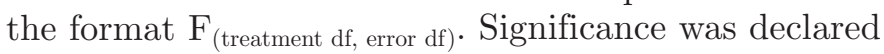
at $P<0.05$.

Age $\left(\mathrm{F}_{1,139}=380.58 ; P<0.001\right)$ and housing $\left(\mathrm{F}_{1,20}=\right.$ 26.93; $P<0.001)$ both affected the amount of starter calves consumed (Figure $1 \mathrm{~A}$ ), but we found no interaction between age and housing $\left(\mathrm{F}_{1,139}=1.67 ; P=0.20\right)$. Intake [geometric mean $(95 \% \mathrm{CI})$ ] over the entire experiment was higher for pair versus individually housed calves $[0.89(0.72-1.08)$ vs. $0.48(0.42-0.56) \mathrm{kg} / \mathrm{d}]$. Body weight increased with age $\left(\mathrm{F}_{1,247}=2334.22 ; P\right.$ $<0.001$; Figure 1 B), but did not vary with treatment $\left(\mathrm{F}_{1,20}=1.08 ; P=0.31\right)$, and we observed no interaction between age and treatment $\left(\mathrm{F}_{1,247}=0.43 ; P=0.51\right)$. At weaning (measured at $63 \pm 0.4 \mathrm{~d}$ of age), paired calves weighed, on average, $84.3 \pm 1.27$ versus $82.5 \pm 1.37 \mathrm{~kg}$ compared to the individually housed calves. Five calves had fecal scores of 4 (1 individual and 4 pair-housed), but none exhibited fever. One calf (individually housed) displayed signs of respiratory infection. On 21 

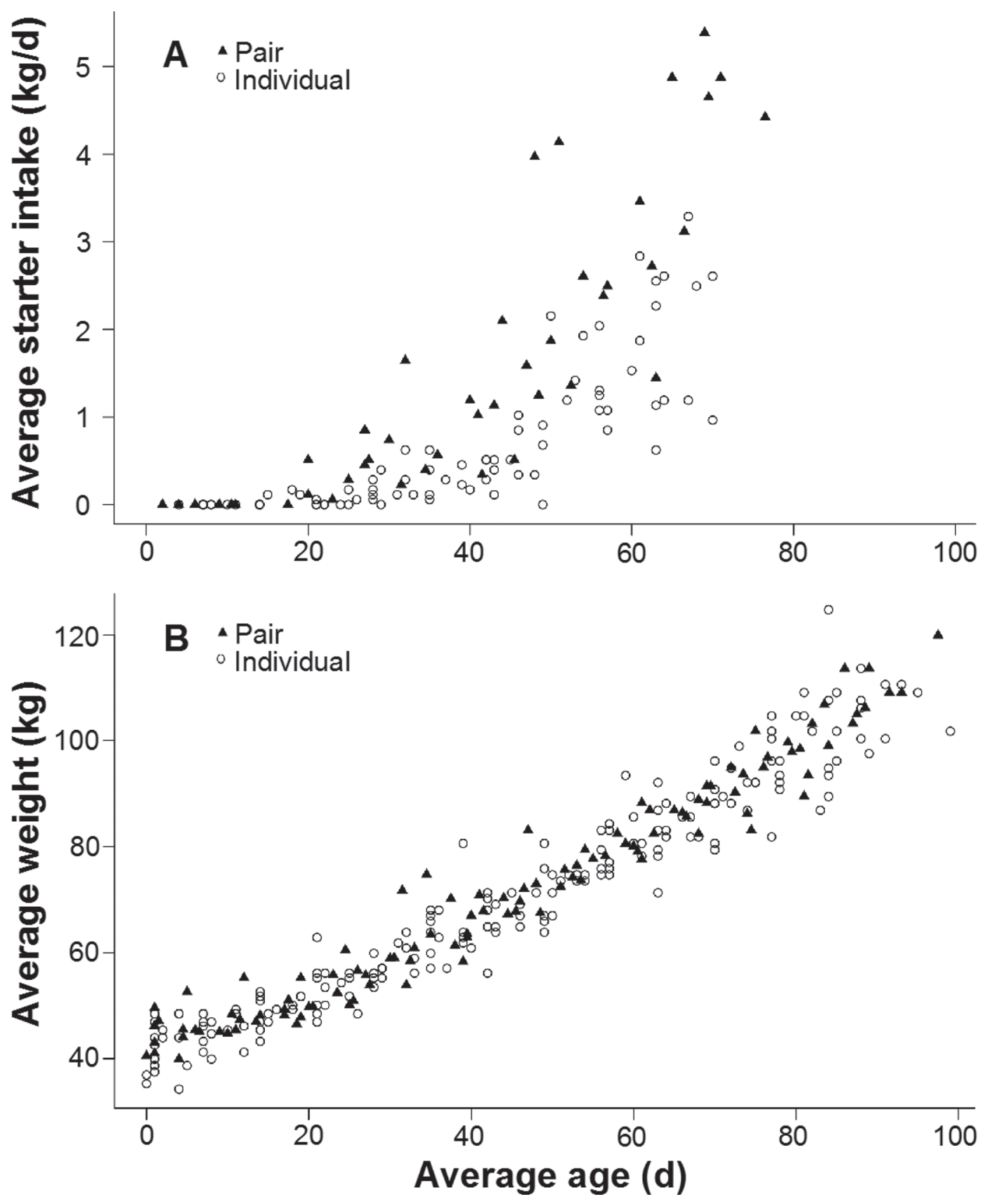

Figure 1. Changes in starter intake (A) and BW (B) in relation to calf age (d). Each point represents data from twice per week (intake) or weekly $(\mathrm{BW})$ measures taken from each individual calf $(\mathrm{n}=14$ calves housed in individual pens; empty circle) or pairs of calves $(\mathrm{n}=8$ pairs of calves housed in a paired pen; solid triangle).

occasions, we recorded body temperatures $\geq 39.5^{\circ} \mathrm{C}(16$ different calves; 7 pair-housed, 9 individually housed). On 14 of these days, temperatures within the hutch exceeded $25^{\circ} \mathrm{C}$.

Pair-housed calves consumed more of the novel food than individually housed calves $(150 \pm 27$ vs. $58 \pm 20$ $\mathrm{g} / 30 \mathrm{~min} ; \mathrm{F}_{1,18}=9.22 ; P<0.01 ;$ Figure 2$)$. Age $\left(\mathrm{F}_{1,18}\right.$ $=5.45 ; P=0.03)$ also affected novel feed intake, but we noted no interaction between age and treatment $(P$ $=0.27$ ). Group housing did not affect the latency to approach the novel feed. Over 14 wk of study, cross sucking was noted 5 times (out of a total of 651 scans) in 4 different pairs.

The effect of social housing on calf performance and behavior has received considerable attention (Jensen et al., 1997; De Paula Vieira et al., 2010), and recently 
interest has increased in using hutches to pair-house calves (Cobb et al., 2014; Pempek et al., 2016; Wormsbecher et al., 2017). Cobb et al. (2014) reported improved performance in group-housed calves compared with individually housed calves, but their results may not apply to conditions on many commercial farms given that group hutches $(2.26 \times 2.69 \mathrm{~m})$ were used. Pempek et al. (2016) also reported that pair-housed calves in hutches tended to have better weight gains compared with individually housed calves, but these calves were fed less than $5 \mathrm{~L} / \mathrm{d}$ of milk and both individual and paired calves had access to just a single hutch. Wormsbecher et al. (2017) provided 2 calves with 2 hutches and singly housed calves 1 hutch, but calves did not enter the study until $24 \mathrm{~d}$ and the study focused on space usage and social behaviors rather than growth and feed intake. Our study builds on these previous studies by comparing individual versus pair housing of calves reared in hutches on a commercial farm, but controlling for space per calf, providing high milk allowances delivered through nipple bottles during the entire milk feeding process, and following performance, feed intake, and reaction to novelty.

We found that socially housed calves are less food neophobic, suggesting that these calves would be less likely to avoid new foods when subjected to diet changes later in life. As calves age, they typically experience a variety of transitions including movement to new pens (Heinrichs et al., 1987) and changes in diets (Sweeney et al., 2010). Practices that reduce fear of novelty, such as social rearing, may make these transitions easier. Our results are consistent with Costa et al. (2014), who found that, when raised in complex social environ-

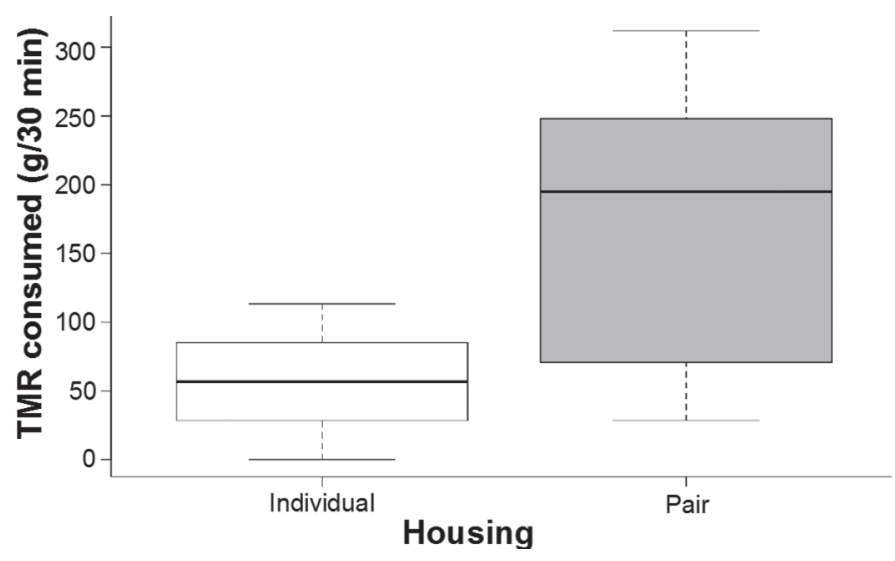

Figure 2. Intake of novel feed (g/30 min) for individually housed ( $\mathrm{n}=14$ calves housed in individual pens $)$ and pair-housed calves $(\mathrm{n}=$ 8 pairs of calves housed in paired pens). Calves were offered a novel feed (TMR) for $30 \mathrm{~min}$ at $60 \mathrm{~d}$ of age. Box plots show medians (solid horizontal line), 25th and 75th percentiles (boundaries of the box), and 10th and 90th percentiles (boundaries of the error bars). ments, calves are less food neophobic compared with when reared individually. Pair-housed calves have been reported to be more likely to explore (Jensen et al., 1997). Calves in the different housing treatments in the current study did not differ in latency to approach the feed; we speculated that this was due to our decision to use the same bucket type and location as was used to provide the calf starter routinely fed on this farm.

In addition to eating more novel feed, pair-housed calves in our study consumed more calf starter. These results complement previous work showing that earlypaired calves eat more starter than individually housed calves (Bernal-Rigoli et al., 2012). All calves in our study were encouraged to eat starter using step-down weaning, where milk was gradually decreased in 2 steps (Khan et al., 2007). Other studies have used social housing to encourage feed intake. For example, lambs are more willing to eat more food when housed in social groups (Provenza and Burritt, 1991), and calves will consume more food when in groups (Phillips, 2004; Costa et al., 2015). Group-housed calves eat more concentrate than individually housed calves before and after weaning (Miller-Cushon and DeVries, 2016). This behavior may be a result of social facilitation, a feeding response elicited by seeing another animal feeding (Launchbaugh and Howery, 2005).

Despite the benefits in increased solid feed intake, we failed to observe differences in BW gains. Our use of the weight measuring tape may have contributed to some measurement error, although several studies have reported that this method provides reliable estimates of BW (Heinrichs et al., 1992; Bond et al., 2015). Other studies comparing pair to individually housed calves fed similar volumes of milk have found similar growth rates (De Paula Vieira et al., 2010; Duve and Jensen, 2012). The paired calves may have used the extra energy intake from the starter for activity rather than weight gain. For example, grouped calves fed high milk allowances play more often (Duve et al., 2012; Jensen et al., 2015). An increase in activity may have also led to differences in body composition. For example, veal calves raised in a group pen have less intramuscular fat than calves raised in individual crates (Andrighetto et al., 1999).

We rarely observed cross sucking. Pempek et al. (2016) reported cross sucking in pair-housed calves, but their study used bucket feeding and low milk allowances (management practices known to increase the risk of cross sucking; Jensen and Budde, 2006). Calves fed from buckets are highly motivated to suck (Hammell et al., 1988) and engage in nonnutritive sucking (Friend and Dellmeier, 1988; Margerison et al., 2003). Feeding calves from a nipple allows them to suck naturally (Appleby et al., 2001) and decreases cross sucking 
(Jensen and Budde, 2006). The combination of nipple feeding and high milk allowance allows for improved growth (Jasper and Weary, 2002). We concluded that these practices should be seen as requirements to promote natural milk feeding behavior and may be especially important when calves are socially housed.

In conclusion, pair housing allows for increased starter intake and decreased fearfulness of novel foods. Pairing of calves by joining adjacent hutches provides a practical method for providing social contact on commercial dairies.

\section{ACKNOWLEDGMENTS}

Special thanks to Brent Fawcett, Lisa McCrea, and Kelsey Patterson from Agwest Veterinary Group (Abbotsford, BC, Canada) for their help throughout the study. We are also grateful to the collaborating farm for allowing us to run this trial and for help throughout the experiment. We thank Antoine Buteau, Lidiane Marcondes, and Chloe Slessor for help with data collection, João Costa (UBC Animal Welfare Program) for help with the food neophobia test, and Julia Lomb (UBC Animal Welfare Program) for guidance with the statistical analysis. This work was supported by funds from the Natural Sciences and Engineering Research Council (NSERC; Ottawa, ON, Canada) Industrial Research Chair Program, with industry contributions from the Dairy Farmers of Canada (Ottawa, ON, Canada), British Columbia Dairy Association (Burnaby, BC, Canada), Westgen Endowment Fund (Milner, BC, Canada), Intervet Canada Corporation (Kirkland, QC, Canada), Novus International Inc. (Oakville, ON, Canada), Zoetis (Kirkland, QC, Canada), BC Cattle Industry Development Fund (Kamloops, BC, Canada), Alberta Milk (Edmonton, AB, Canada), Valacta (St. Anne-de-Bellevue, QC, Canada), and CanWest DHI (Guelph, ON, Canada).

\section{REFERENCES}

Andrighetto, I., F. Gottardo, D. Andreoli, and G. Cozzi. 1999. Effect of type of housing on veal calf growth performance, behaviour and meat quality. Livest. Prod. Sci. 57:137-145. https://doi.org/ 10.1016/S0301-6226(98)00170-5.

Appleby, M. C., D. M. Weary, and B. Chua. 2001. Performance and feeding behaviour of calves on ad libitum milk from artificial teats. Appl. Anim. Behav. Sci. 74:191-201. https://doi.org/10.1016/ S0168-1591(01)00171-X.

Bernal-Rigoli, J. C., J. D. Allen, J. A. Marchello, S. P. Cuneo, S. R. Garcia, G. Xie, L. W. Hall, C. D. Burrows, and G. C. Duff. 2012 Effects of housing and feeding systems on performance of neonatal Holstein bull calves. J. Anim. Sci. 90:2818-2825. https://doi.org/ 10.2527/jas.2011-4722.

Boissy, A., and P. Le Neindre. 1997. Behavioral, cardiac and cortisol responses to brief peer separation and reunion in cattle. Physiol. Behav. 61:693-699. https://doi.org/10.1016/S0031-9384(96)00521 -5 .
Bolt, S. L., N. K. Boyland, D. T. Mlynski, R. James, and D. P. Croft. 2017. Pair housing of dairy calves and age at pairing: Effects on weaning stress, health, production and social networks. PLoS One 12:e0166926. https://doi.org/10.1371/journal.pone.0166926.

Bond, G. B., M. A. G. von Keyserlingk, N. Chapinal, E. A. Pajor, and D. M. Weary. 2015. Among farm variation in heifer BW gains. Animal 9:1884-1887. https://doi.org/10.1017/S175173111500097X.

Cobb, C. J., B. S. Obeidat, M. D. Sellers, A. R. Pepper-Yowell, D. L. Hanson, and M. A. Ballou. 2014. Improved performance and heightened neutrophil responses during the neonatal and weaning periods among outdoor group-housed Holstein calves. J. Dairy Sci. 97:930-939. https://doi.org/10.3168/jds.2013-6905.

Costa, J. H. C., R. R. Daros, M. A. G. von Keyserlingk, and D. M. Weary. 2014. Complex social housing reduces food neophobia in dairy calves. J. Dairy Sci. 97:7804-7810. https://doi.org/10.3168/ jds.2014-8392.

Costa, J. H. C., R. K. Meagher, M. A. G. von Keyserlingk, and D. M. Weary. 2015. Early pair housing increases solid feed intake and weight gains in dairy calves. J. Dairy Sci. 98:6381-6386. https:// doi.org/10.3168/jds.2015-9395.

Costa, J. H. C., M. A. G. von Keyserlingk, and D. M. Weary. 2016. Invited review: Effects of group housing of dairy calves on behavior, cognition, performance, and health. J. Dairy Sci. 99:2453-2467. https://doi.org/10.3168/jds.2015-10144.

De Paula Vieira, A., M. A. G. von Keyserlingk, and D. M. Weary. 2010. Effects of pair versus single housing on performance and behavior of dairy calves before and after weaning from milk. J. Dairy Sci. 93:3079-3085. https://doi.org/10.3168/jds.2009-2516.

Duve, L. R., and M. B. Jensen. 2012. Social behavior of young dairy calves housed with limited or full social contact with a peer. J. Dairy Sci. 95:5936-5945. https://doi.org/10.3168/jds.2012-5428.

Duve, L. R., D. M. Weary, U. Halekoh, and M. B. Jensen. 2012. The effects of social contact and milk allowance on responses to handling, play, and social behavior in young dairy calves. J. Dairy Sci. 95:6571-6581. https://doi.org/10.3168/jds.2011-5170.

Friend, T. H., and G. R. Dellmeier. 1988. Common practices and problems related to artificially rearing calves: An ethological analysis. Appl. Anim. Behav. Sci. 20:47-62. https://doi.org/10.1016/0168 -1591(88)90125-6.

Hammell, K. L., J. H. M. Metz, and P. Mekking. 1988. Sucking behaviour of dairy calves fed milk ad libitum by bucket or teat Appl. Anim. Behav. Sci. 20:275-285. https://doi.org/10.1016/0168 $-1591(88) 90052-4$.

Heinrichs, A. J., R. E. Graves, and N. E. Kiernan. 1987. Survey of calf and heifer housing on Pennsylvania dairy farms. J. Dairy Sci. 70:1952-1957. https://doi.org/10.3168/jds.S0022-0302(87)80237 -0 .

Heinrichs, A. J., G. W. Rogers, and J. B. Cooper. 1992. Predicting body weight and wither height in Holstein heifers using body measurements. J. Dairy Sci. 75:3576-3581. https://doi.org/10.3168/ jds.S0022-0302(92)78134-X.

Jasper, J., and D. M. Weary. 2002. Effects of ad libitum milk intake on dairy calves. J. Dairy Sci. 85:3054-3058. https://doi.org/10.3168/ jds.S0022-0302(02)74391-9.

Jensen, M. B., and M. Budde. 2006. The effects of milk feeding method and group size on feeding behavior and cross-sucking in grouphoused dairy calves. J. Dairy Sci. 89:4778-4783. https://doi.org/ 10.3168/jds.S0022-0302(06)72527-9.

Jensen, M. B., L. R. Duve, and D. M. Weary. 2015. Pair housing and enhanced milk allowance increase play behavior and improve performance in dairy calves. J. Dairy Sci. 98:2568-2575. https://doi .org/10.3168/jds.2014-8272.

Jensen, M. B., K. S. Vestergaard, C. C. Krohn, and L. Munksgaard 1997. Effect of single versus group housing and space allowance on responses of calves during open-field tests. Appl. Anim. Behav Sci. 54:109-121. https://doi.org/10.1016/S0168-1591(96)01183-5.

Khan, M. A., H. J. Lee, W. S. Lee, H. S. Kim, S. B. Kim, K. S. Ki J. K. Ha, H. G. Lee, and Y. J. Choi. 2007. Pre- and postweaning performance of Holstein female calves fed milk through step-down and conventional methods. J. Dairy Sci. 90:876-885. https://doi .org/10.3168/jds.S0022-0302(07)71571-0. 
Khan, M. A., D. M. Weary, and M. A. G. von Keyserlingk. 2011. Invited review: Effects of milk ration on solid feed intake, weaning, and performance in dairy heifers. J. Dairy Sci. 94:1071-1081. https://doi.org/10.3168/jds.2010-3733.

Launchbaugh, K. L., and L. D. Howery. 2005. Understanding landscape use patterns of livestock as a consequence of foraging behavior. Rangeland Ecol. Manag. 58:99-108. https://doi.org/10.2111/ 03-146.1.

Margerison, J. K., T. R. Preston, N. Berry, and C. J. C. Phillips. 2003. Cross-sucking and other oral behaviours in calves, and their relation to cow suckling and food provision. Appl. Anim. Behav. Sci. 80:277-286. https://doi.org/10.1016/S0168-1591(02)00231-9.

Miller-Cushon, E. K., and T. J. DeVries. 2016. Effect of social housing on the development of feeding behavior and social feeding preferences of dairy calves. J. Dairy Sci. 99:1406-1417. https://doi.org/ 10.3168/jds.2015-9869.

Pempek, J. A., M. L. Eastridge, S. S. Swartzwelder, K. M. Daniels, and T. T. Yohe. 2016. Housing system may affect behavior and growth performance of Jersey heifer calves. J. Dairy Sci. 99:569578. https://doi.org/10.3168/jds.2015-10088.

Pettersson, K., C. Svensson, and P. Liberg. 2001. Housing, feeding and management of calves and replacement heifers in Swedish dairy herds. Acta Vet. Scand. 42:465-478. https://doi.org/10.1186/1751 $-0147-42-465$.
Phillips, C. J. C. 2004. The effects of forage provision and group size on the behavior of calves. J. Dairy Sci. 87:1380-1388. https://doi .org/10.3168/jds.S0022-0302(04)73287-7.

Provenza, F. D., and E. A. Burritt. 1991. Socially induced diet preference ameliorates conditioned food aversion in lambs. Appl. Anim. Behav. Sci. 31:229-236. https://doi.org/10.1016/0168 -1591(91)90007-K.

Sweeney, B. C., J. Rushen, D. M. Weary, and A. M. de Passillé. 2010. Duration of weaning, starter intake, and weight gain of dairy calves fed large amounts of milk. J. Dairy Sci. 93:148-152. https:// doi.org/10.3168/jds.2009-2427.

USDA. 2016. Dairy 2014, Dairy Cattle Management Practices in the United States, 2014. USDA, Fort Collins, CO.

Valníčková, B., I. Stěhulová, R. Šárová, and M. Špinka. 2015. The effect of age at separation from the dam and presence of social companions on play behavior and weight gain in dairy calves. J. Dairy Sci. 98:5545-5556. https://doi.org/10.3168/jds.2014-9109.

Wormsbecher, L., R. Bergeron, D. Haley, A. M. de Passillé, J. Rushen, and E. Vasseur. 2017. A method of outdoor housing dairy calves in pairs using individual calf hutches. J. Dairy Sci. 100:7493-7506. https://doi.org/10.3168/jds.2017-12559. 